KS. JÓZEF SZYMAŃSKI* - LUBLIN

\title{
STAN I SYTUACJA CERKWI PRAWOSLAWNEJ NA TERENIE OBWODU WINNICKIEGO W LATACH 1941-1965
}

Obwód winnicki na Podolu (Ukraina) został utworzony 27 lutego 1932 r. i zajmuje 26,5 tys. $\mathrm{km}^{2}$ powierzchni ${ }^{1}$. Na jego terytorium w 1937 r. było 1.899 wiosek, 16 osiedli robotniczych i 7 miast $^{2}$, które zamieszkiwało w 1941 r. -2.390 .000$ osób, a w 1946 r. - 2.037.000³. Do rewolucji październikowej w obwodzie otwartych było 1.100 cerkwi prawosławnych ${ }^{4}$. Jak twierdzi P. Panczenko: „, na początku lat dwudziestych na Ukrainie cerkiew znajdowała się niemal w każdej wiosce"s.

* Ks. Józef Szymański - dr historii Kościoła, adiunkt, dyrektor Instytutu Badań nad Polonią i Duszpasterstwem Polonijnym KUL.

${ }^{1}$ Політичні репресії на Поділлі (20-30 рр XX cm.), ред. І. Т. Паламар, Вінниця 1999, s. 37. Obwód winnicki został utworzony w dotychczasowych granicach guberni podolskiej, funkcjonującej w latach 1793-1925; А.Ф. Олійник, I. Л. Яковенко, Вінницька область, w: Радянська Енциклопедія історіi України, t. 1, Київ 1969, s. 303-307; М . Л. Б Б б і й, М.Ф. Присяжнюк, В.О.Птущенко, І. П. Пшук, Й.Г. Тельман, Вінницька область, w: Історія міст і сіл Украӥнської РСР. Вінницька область, red. А.Ф. Олійник, Київ 1972, s. 9. Obwód winnicki graniczy od południowego zachodu z Republiką Mołdawia, od zachodu, z obwodami: czerniowieckim i chmielnickim, od północy - żytomierskim, od wschodu - kijowskim, czerkaskim, kirwogradzkim i od południa - odeskim. W jego skład wchodziło 69 rejonów. 22 września 1937 r. na skutek nowego podziału administracyjnego z części rejonów obwodu winnickiego utworzono obwód kamieniecko-podolski (obecnie chmielnicki), kilka rejonów włączono też do obwodu żytomierskiego. Jednocześnie do obwodu winnickiego przyporządkowano kilka rejonów obwodu kijowskiego. W wyniku tego podziału obwód liczył 42 rejony. W styczniu 1954 r. został on jeszcze uszczuplony o rejon monasterzyski, który odłączono do nowoutworzonego obwodu czerkaskiego. W 1963 r. zamiast dotychczas funkcjonujacych 42 rejonów, utworzono 25.

2 Державний Архів Вінницької Області (dalej: ДАВО), ф. Р-2700, оп. 7с, спр. 345, арк. 223.

${ }^{3}$ P. Eberhardt, Przemiany narodowościowe na Ukrainie XX wieku, Warszawa 1994, s. 178.

${ }^{4}$ ДАВО, Р-2700, 7c, 345, s. 223.

5 П. Пан че н ко, Рулігія в українському суспільстві, w: Україна друга половина ХХ століття. Нариси історії, red. П. Панченко, Київ 1997, s. 201. 
Od 1932 r. rozpoczął się jednak proces masowego zamykania budynków modlitewnych, kościołów i cerkwi. Realizowano go z taką konsekwencją, że już w 1937 r. oficjalnie nie istniała żadna wspólnota religijna ${ }^{6}$. O tej sytuacji napisał przewodniczący Rady ds. Kultów Religijnych (dalej: Rds.KR) przy Radzie Ministrów (dalej: RM) Ukrainy w 1948 r. w piśmie do swojego przedstawiciela w obwodzie I. Szumkowa: „Z materiałów wynika, że we wszystkich wschodnich obwodach Ukrainy [...] do wojny niemal nigdzie nie było parafii (były w swoim czasie zamknięte)". Przyznał jednocześnie, że absolutna większość funkcjonujących parafii na Ukrainie powstała podczas okupacji niemieckiej?.

Paradoksalnie więc, praktyczna możliwość odrodzenia życia religijnego na Wschodzie zaistniała dopiero po ataku Niemiec na ZSRR 22 czerwca $1941 \mathrm{r}$. W czasie okupacji niemieckiej 1941-1943 na terenie obwodu otwarto $848^{8}$ cerkwi prawosławnych i budynków modlitewnych ${ }^{9}$. Niewątpliwie wpływ na taką sytuację miała decyzja Adolfa Hitlera, który już 16 sierpnia 1941 r. zezwolił kapłanom prawosławnym na prowadzenie działalności duszpasterskiej na okupowanym przez Niemców terytorium ${ }^{10}$. Według informacji pełnomocnika Rds.KR: „Od września 1941 r. na okupowanym przez Niemców terytorium obwodu wspólnoty religijne zaczęły działać oficjalnie, zajmując zamknięte za czasów władzy sowieckiej budynki modlitewne, kościoły i cerkwie"11. W czasie okupacji część obwodu winnickiego na linii Mohylew Podolski - Żmerynka - Berszada była zarządzana przez wojska rumuńskie i wchodziła do Generalnego Gubernatorstwa tzw. Transnistria. Pozostała część została administracyjnie przyporządkowana do tzw. Reichskommisariatu Ukrainy i włączona do Generalnego Żytomierskiego Okrę$\mathrm{gu}^{12}$. Niemcy nie mieli opracowanego spójnego programu polityki religijnej na Wschodzie, często ich decyzje miały charakter doraźny i były wymuszane bieżą-

\footnotetext{
${ }^{6}$ ДАВО, P-2700, 7c, 182, s. 17b; R. D z w o n k o w s k i, Kościót katolicki w ZSRR 1917-1939. Zarys historii, Lublin 1997, s. 241-267.

7 ДАВО, Р-2700, 19, 37, s. 1-2; Б. Ч а п л и ц к и й, И. О с и п о в а, Книга памяти. Мартиролог Католической иеркви в СССР, Москва 2000, s. L.

${ }^{8} \mathrm{~W}$ zależności od sprawozdania składanego przez pełnomocnika Rady ds. Cerkwi prawosławnej liczba ta wahała się od 839 do 848.

${ }^{9}$ ДАВО, Р-2700, 7c, 345, s. 223.

${ }^{10}$ А. В е н ге р, Рим и Москва 1900-1950, Москва 2000, s. 538.

${ }^{11}$ ДАВО, Р-2700, 7c, 182, s. 17b; В. В о й н а л о в и ч, Наступ на етноконфесійні осередки як один із засобів здійснення начіональної політики в Україні (друга пол. 40-х - 50-ті роки ХХ cm.), „3 архівів ВУЧК ГПУ НКВД КГБ” 1/2 (1997), s. 208; А. C h o j n o w s k i, Ukraina, Warszawa 1997, s. 141-149; R. D z w o n k ow s k i, Odrodzenie Kościoła katolickiego na Ukrainie środkowej, południowej $i$ wschodniej w czasie II wojny światowej $i$ bezpośrednio po jej zakończeniu (1941-1948), w: Pasterz i twierdza. Księga Jubileuszowa dedykowana księdzu biskupowi Janowi Olszańskiemu ordynariuszowi diecezji w Kamieńcu Podolskim, red. J. Wołczański, Kraków-Kamieniec Podolski 2001, s. 24-26.

${ }^{12}$ J. H r y c a k, Historia Ukrainy 1772-1999. Narodziny nowoczesnego narodu, Lublin 2000, s. 227; W. A. S e r c zy k, Historia Ukrainy, Wrocław-Warszawa-Kraków 1990², s. 436; Б а б і й, Віннищька область, s. 50; А. Л и с и й, Нариси історї Гніванського костелу 1906-1996, Вінниця 1996, s. 73; t e nże, Віннищький капуцинський монастир, Вінниця 1995, s. 91; E b e r h a r d t, Przemiany narodowościowe, s. 160; В е н г е p, Рим и Москва, s. 540.
} 
cymi potrzebami ludzi wierzących ${ }^{13}$. Stanowisko władz okupacyjnych w tej sprawie zostało również potwierdzone przez Alfreda Rosenberga 13 maja 1943 r. w liście do komisarzy Rzeszy na Wschodzie, w którym domagał się on, aby - w miarę możliwości - starali się ograniczać działalność organizacji religijnych, a jednocześnie popierali wszelkiego rodzaju separatyzmy wyznaniowe ${ }^{14}$. W tym celu, niemieckie władze okupacyjne dokonały rozbicia m.in. w szeregach prawosławia, zezwalając na prowadzenie działalności duszpasterskiej niezależnej od patriarchatu moskiewskiego, Autokefalicznej Ukraińskiej Cerkwi Prawosławnej ${ }^{15}$.

Po wkroczeniu na to terytorium wojsk sowieckich w połowie 1944 r., władze nie mogły już stosować metod wojującego ateizmu realizowanych w latach dwudziestych i trzydziestych, i lekceważyć skonsolidowanych w czasie okupacji rzesz wiernych ${ }^{16}$. Dnia 7 listopada 1943 r. Rada Komisarzy Ludowych (dalej: RKL) podporządkowała działalność Cerkwi prawosławnej powołanej przez siebie Radzie ds. Cerkwi prawosławnej ${ }^{17}$. Cerkiew całkowicie podporządkowano patriarchatowi moskiewskiemu ${ }^{18}$ i włączono do egzarchatu kijowskiego ${ }^{19}$. Diecezja winnicka - obejmująca terytorium obwodu winnickiego - była jedną z 19 diecezji wchodzących w jego skład ${ }^{20}$, jej organizacja i formy działalności określone zostały uchwałami soboru z 31 stycznia $1945 \mathrm{r}^{21}$

${ }^{13}$ Archiwum Diecezji Łuckiej [w posiadaniu Ośrodka Archiwów Bibliotek i Muzeów Kościelnych KUL] (dalej: ADŁ), Kuria Biskupia Łucka (dalej: KBŁ), t. Diecezja żytomierska i kamieniecka. (Generalny komisarz) Generalkommissar w Żytomierzu do biskupa rzymskokatolickiego w Łucku 25 III 1942 r.; M. D ę b o w s k a, Postuga duszpasterska duchowieństwa diecezji tuckiej na kresach wschodnich I RP w czasie II wojny światowej w: Historia et ius. Księga Pamiątkowa ku czci Księdza Profesora Henryka Karbownika, red. A. Dębiński, G. Górski, Lublin 1998, s. 35-36; B e н ге р, Рим и Москва, s. 537.

${ }^{14} \mathrm{~W} . \mathrm{Z}$ a j ą c z k o w s k i, W obliczu rewolucji. (Rosyjskie prawostawie w latach 1917- 44), w: Dar Polski Białorusinom, Rosjanom i Ukraińcom na Tysiąclecie ich Chrztu Świętego, red. K. Podlaski, Londyn 1989, s. 96; В о й н а л о в и ч, Наступ на етноконфесійні осередки, s. 211.

${ }^{15} \mathrm{~S}$ e r c z y k, Historia Ukrainy, s. 438.

${ }^{16}$ В о й н а л о в и ч, Наступ на етноконфесійні осередки, s. 208.

${ }_{17}$ ДАВО, Р-2700, 7c, 10, s. 1-3; В . В о й н а л о в и ч, Що насправді коїлось у патріарших палатах. Маловідомі документи про опозииійний рух у Руській Православній Церкві, „3 архівів ВУЧК ГПУ НКВД КГБ” 1(1994), s. 157.

${ }^{18}$ Й. Л о р т ц, История Церкви. Рассмотренная в связи с историей идей, t. 2: Новое время, Москва 2000, s. 467-468; Современные религии и их роль, „Наука и религия” 1(1963), s. 77.

${ }^{19} \mathrm{~J}$. T o fi $1 \mathrm{u}$ k, Kościót prawosławny, w: Ku chrześcijaństwu jutra. Wprowadzenie do ekumenizmu, red. W. Hryniewicz OMI, J.S. Gajek MIC, ks. S.J. Koza, Lublin 1996, s. 113.

${ }^{20}$ M. T. S t a s z e w s k i, Polityka wyznaniowa europejskich państw socjalistycznych, w: Polityka wyznaniowa. Tło-warunki-realizacja, red. M. T. Staszewski, W. Mysłek, Warszawa 1975, s. 115.

${ }^{21}$ Dokument 137: Положение об управлении Русской Православной Церковью (31.1.1945), w: Русская Православная Церковь в советское время (1917-1991). Материальы и документы по истории отношений между государством и Церковью, кн. 1, red. Г. Штриккер, Москва 1995, s. 349-355; А. Ж у ко в с ь к и й, Сучасний стан релігії й иеркви під совєтами, зокрема в УССР, w: Релігія в житті українського народу. Зборник матеріялів наукової конферениіі у Рокка di nana (18-20) X 1963, red. В. Янев, München-Rom-Paris 1966, s. 51. 
RKL 1 grudnia 1944 r. zatwierdziła prawo regulujące zasady funkcjonowania Cerkwi prawosławnej i uzupełniła je specjalnym postanowieniem Józefa Stalina $^{22}$. Zdaniem przewodniczącego Rds.KR Aleksandra Puzina Cerkiew była uprzywilejowana wobec innych wyznańn ${ }^{23}$. Według obowiązującego prawa „,W wypadkach, kiedy większa grupa wiernych prosiła o otwarcie cerkwi w budynku, który zachował cerkiewny wygląd i przedmioty kultu, dotychczas pozostawał nie zajęty i nie zamknięty na podstawie decyzji władz, taka prośba podlegała pozytywnemu rozpatrzeniu, niezależnie od ilości otwartych już cerkwi w mieście lub rejonie"24. Ponadto władze każdego szczebla zobowiązano do udzielenia prawosławnym parafiom niezbędnej pomocy przy remoncie cerkwi, uwzględniając dostarczenie potrzebnych materiałów budowlanych. Parafie uzyskały wtedy również prawo do nabycia dzwonów cerkiewnych i wykorzystywania istniejących. Struktury Cerkwi prawosławnej uzyskały ograniczoną osobowość prawną, zezwalającą im na posiadanie środków transportu, wytwarzanie przedmiotów kultu religijnego i sprzedawanie ich wspólnotom wiernych, zezwolenie na ,arendę, budowę i nabywanie na własność budynków dla potrzeb cerkwi za zgodą pełnomocnika Rady ds. Cerkwi prawosławnej"25. Na mocy wspomnianego postanowienia klasztory męskie i żeńskie uzyskały od Stalina tymczasowo - „do chwili wydania nowych postanowień" - list żelazny, który zachowywał stan ich posiadania ${ }^{26}$. Zmiany prawne nastąiłi dopiero $\mathrm{w} 1961 \mathrm{r}^{27}$

Według danych pełnomocnika Rady ds. Cerkwi prawosławnej obwodu winnickiego z 1 września 1944 r., na jego terytorium funkcjonowało 839 wspólnot prawosławnych, 4 klasztory żeńskie ${ }^{28}$, i 1 klasztor męski otwarty w czasie okupacji, we wsi Zielony Gaj (działał do 1944 r.) ${ }^{29}$. Z tych 839 cerkwi - zdaniem pełnomocnika - 147 znajdowało się w budynkach należących do organizacji społecznych i państwowych (zajętych przez wiernych w czasie okupacji). Z kolei z tych 147, w dniach od 21 marca do 1 listopada zwolniono 61, pozostało 86. Z tych 61, 24 zwolniono na podstawie decyzji Rady Obwodowej (dalej: RO), 13 pomieszczeń zaproponowały organizacje, a 47 poszukiwało sobie miejsca samemu, 1 rozwiązano, bo nie miała pomieszczenia (w rejonie szpikowskim) ${ }^{30}$. W działalność duszpasterską zaangażowanych było 194 kapłanów i 4 diakonów $^{31}$. Wielu duchownych nie miało uregulowanego swojego statusu w diecezji, wielu kapłanów było członkami kołchozów, pracowało w charakterze księgowych. Z racji swoich orientacji: autokefalnej i odnowicielskiej biskup musiał ich powtórnie święcić, by

\footnotetext{
22 ДАВО, Р-2700, 7c, 13, s. 22.

${ }^{23}$ ДАВО, Р-2700, 19, 63, s. 44.

${ }^{24}$ Tamże, s. 57.

${ }^{25}$ ДАВО, Р-2700, 7c, 13, s. 22.

${ }^{26}$ Tamże, s. 23.

27 ДАВО, Р-2700, 19, 63, s. 44, 57.

28 ДАВО, Р-2700, 19, 1, s. 4ab, 13.

${ }^{29}$ ДАВО, Р-2700, 19, 3, s. 31.

30 ДАВО, Р-2700, 19, 1, s. 3.

${ }^{31}$ Tamże, s. 5.
} 
mogli uzyskać prawo do pracy duszpasterskiej na terenie diecezji ${ }^{32}$. Działania te wspierał administracyjnie pełnomocnik, wysyłając dyrektywy do wszystkich Rad Rejonowych, informując o zakończeniu rejestracji parafii i duchowieństwa do 1 maja 1945 r. Zastrzegał też, by duchowieństwa nie mającego jego pozwolenia, nie dopuścić do posługi na terenie diecezji ${ }^{33}$. Ponadto władze zwierzchnie w Kijowie zobowiązały pełnomocnika do dokładnego przeanalizowania danych osób rejestrujących się jako duchowni, w przypadku osób przybyłych z innych obwodów dane analizowali pracownicy służby bezpieczeństwa, decydując w ostateczności o ich kwalifikacjach duszpasterskich ${ }^{34}$. Ze względu zaś na słabe wykształcenie duchowieństwa pełnomocnik sprzeciwił się zorganizowaniu przy biskupie komitetu misyjnego, zadaniem którego była by praca wśród „sektantów”35. Nie protestował zaś mimo próśb ze strony duchowieństwa, kiedy zobowiązano kapłanów do świadczenia na rzecz państwa, rocznie po „80 kg mięsa i 240 sztuk jaj”’36.

Administracja diecezją była utrudniona z uwagi na częstą nieobecność biskupa. Utrudniało to bieżącą rejestrację duchowieństwa w urzędach państwowych, konieczną przy podejmowaniu obowiązków duszpasterskich. Sama osoba biskupa Maksyma (Wasilij Baczyński) była bardzo kontrowersyjna. W opinii bliskiego współpracownika biskupa, Pisarewskiego Sawy powątpiewano, co do rzeczywistych predyspozycji biskupa, jako rządcy diecezji. Ponieważ „bp nie znał języka starosłowiańskiego, czytał bardzo słabo i w ogóle budził wiele wątpliwości”. $\mathrm{Z}$ analogicznymi wątpliwościami występowali m.in. - protirej M. Łopuchow, W. Ryziuk - starosta soboru, Jasnowskij (były generał - major wojsk carskich). Niemniej, na utrzymanie biskupa i jego urzędu świadczono pomoc finansową po 140 rubli z każdej parafii. Ponadto każdy ksiądz wpłacał po 100, psalmista (organista) -50 , starosta cerkwi - 25 rubli $^{37}$. Budzącego swoją postawą nieufność biskupa Maksyma, 18 czerwca 1945 r. zastąpił biskup Warłam. Oficjalne objęcie obowiązków nastąpiło jednak znacznie później ${ }^{38}$.

Tabela 1. Sytuacja Cerkwi prawosławnej na terenie obwodu wg stanu z 1 września 1944 r. i w pierwszym półroczu 1946 r.

\begin{tabular}{|c|c|c|c|c|c|c|}
\hline Nazwa rejonu & $\begin{array}{c}\text { Liczba } \\
\text { cerkwi }\end{array}$ & $\begin{array}{c}\text { Liczba } \\
\text { duchow- } \\
\text { nych }\end{array}$ & $\begin{array}{c}\text { Liczba } \\
\text { klasztorów }\end{array}$ & $\begin{array}{c}\text { Liczba } \\
\text { zakonnic }\end{array}$ & $\begin{array}{c}\text { Liczba } \\
\text { cerkwi } \\
\text { w których } \\
\text { nie } \\
\text { sprawuje } \\
\text { się liturgii }\end{array}$ & $\begin{array}{c}\text { Liczba } \\
\text { cerkwi } \\
\text { zamknię- } \\
\text { tych } \\
\text { przez } \\
\text { władzę }\end{array}$ \\
\hline Bar & $\mathbf{2}$ & $\mathbf{3}$ & $\mathbf{4}$ & $\mathbf{5}$ & $\mathbf{6}$ & $\mathbf{7}$ \\
\hline
\end{tabular}

\footnotetext{
${ }^{32}$ Tamże, s. 16.

${ }^{33}$ ДАВО, Р-2700, 19, 2, s. 6.

${ }^{34}$ ДАВО, Р-2700, 19, 6, s. 34.

35 ДАВО, Р-2700, 19, 2, s. 39.

${ }^{36}$ ДАВО, Р-2700, 19, 3, s. 32, 38.

37 ДАВО, Р-2700, 19, 2, s. 1 a.

${ }^{38}$ Tamże, s. 11, 15.
} 


\begin{tabular}{|c|c|c|c|c|c|c|}
\hline Berszadź & 26 & - & $1^{\mathrm{a}}$ & & & \\
\hline Bracław & $25(16)^{\mathrm{b}}$ & 6 & & & 4 & 1 \\
\hline Winnica & 29 & - & & & & \\
\hline Woronowica & $16(16)$ & 10 & & & & \\
\hline Hajsen & $23(33)$ & 22 & & & & \\
\hline Daszew & $14(16)$ & 7 & & & & \\
\hline 1 & 2 & 3 & 4 & 5 & 6 & 7 \\
\hline Dzulińsk & 18 & - & & & & \\
\hline Żmerynka & $21(21)$ & 12 & 1 & 24 & & \\
\hline Ilińce & $10(15)$ & 7 & & & & \\
\hline Kalinówka & 24 & - & & & & \\
\hline Koziatyn & $12(13)$ & 8 & & & & \\
\hline Komsomolsk & $8(10)$ & 7 & & & & \\
\hline Kryżopol & $28(28)$ & 10 & & & & \\
\hline Kopajgród & $27(26)$ & 6 & & & & \\
\hline Lipowiec & 11 & - & & & 2 & 2 \\
\hline Lityń & $26(26)$ & 13 & & & & \\
\hline Monasterzyska & $13(13)$ & 9 & & & & \\
\hline $\begin{array}{l}\text { Murowane } \\
\text { Kurvłowce }\end{array}$ & 19 (19) & 9 & 1 & 14 & & \\
\hline $\begin{array}{l}\text { Kuryłowce } \\
\text { Mohylew Podolski } \\
\end{array}$ & $29(29)$ & 11 & & & & \\
\hline Niemirów & $16(15)$ & 11 & 1 & 58 & 3 & 3 \\
\hline Obodówka & $11(11)$ & 5 & & & & \\
\hline Olgopol & $13(12)$ & 6 & & & & \\
\hline Oratów & 9 & & & & & \\
\hline Pohrebyszcze & $26(26)$ & 10 & & & & \\
\hline Pieszczanka & $19(13)$ & 6 & & & & \\
\hline Plisków & $11(12)$ & 4 & & & & \\
\hline Samhorodok & 9 & & & & & \\
\hline Sitków & $17(15)$ & 9 & & & & \\
\hline Stanisławczyk & $2(12)$ & 9 & & & 2 & \\
\hline Tomaszpol & $32(30)$ & 11 & & & & \\
\hline Turbów & $11(10)$ & 7 & & & & \\
\hline Trostianiec & $15(8)$ & 8 & & & & \\
\hline Teplik & $26(27)$ & 15 & & & & \\
\hline Tulczyn & $28(30)$ & 17 & & & & \\
\hline Tywrów & $27(21)$ & 10 & & & & \\
\hline Ułanów & $20(17)$ & 10 & & & 1 & \\
\hline Chmielnik & $24(25)$ & 17 & & & 1 & 1 \\
\hline Czeczelnik & $11(11)$ & 4 & & & & \\
\hline Czerniowce & $19(18)$ & 8 & & & & \\
\hline Szarogród & $28(31)$ & 13 & & & & \\
\hline Szpików & 16 & - & & & & \\
\hline Jampol & $19(21)$ & 8 & & & & \\
\hline \multirow[t]{2}{*}{ Jaroszynka } & $14(14)$ & 6 & & & 1 & 1 \\
\hline & $839(660)$ & 326 & 4 & 137 & 14 & 8 \\
\hline
\end{tabular}

Źródto: ДАВО, P-2700, 19, 1, s. 4ab, 13.

a ДАВО, P-2700, 19, 1, s.19. W wykazie nie podano klasztoru w Berszadzi, który zamknięto 2 maja 1945 r. Jak argumentowano byto tam tylko 10 osób, a potrzebny byt na dom dziecka.

${ }^{\mathrm{b}}$ Dane w nawiasach i rubryce liczba duchownych dotycza pierwszego pótrocza $1946 \mathrm{r}$. ДАВО, P-2700, 19, 3, s. 28.

Z raportu przedstawionego przez A. Ustenko, zastępcę przewodniczącego RO w Winnicy dowiadujemy się, że ,[...] od 1 stycznia 1945 r. na terytorium obwodu 
winnickiego funkcjonowało 997 wspólnot religijnych" różnych wyznań ${ }^{39}$. Wśród nich oficjalnie były zarejestrowane 832 wspólnoty należące do Cerkwi prawosławnej ${ }^{40}$. Dane te nie były jednak pełne. W praktyce jak wyjaśniał przełożonym w Moskwie i Kijowie pełnomocnik Rds.KR F. Czepurow - „,wiele budynków kultu funkcjonowało bez rejestracji, ponieważ wierni uważali, że oni legalnie wykonują obrzędy religijne, powołując się przy tym na działalność innych wyznań"41. $\mathrm{Z}$ tego względu w instrukcji nr 3 z 29 kwietnia 1946 r. przewodniczący Rds.KR w Moskwie J. Sadowski wyjaśnił swoim podwładnym, że ,za faktycznie działającą wspólnotę należy uważać taką, która ma specjalny budynek modlitewny (meczet, synagogę, kościół, cerkiew) lub pomieszczenie specjalnie przystosowane do celów modlitewnych. Ta wspólnota powinna mieć duszpasterza, stałą liczbę wiernych i sprawować regularnie liturgię od momentu powstania do chwili obecnej" 42 .

Władze centralne w Moskwie analizując sprawozdania przesyłane Radzie ds. Cerkwi prawosławnej za III kwartał 1948 r. zauważyły, że „obwód winnicki ma na swym terenie najwięcej cerkwi, różnica między liczbą działających cerkwi a liczbą duchowieństwa jest większa niż w jakimkolwiek obwodzie na Ukrainie (438 duchownych na 780 cerkwi) ${ }^{43}$. Liczba duchowieństwa była znacznie większa od tej ujętej w sprawozdaniu. Przy tym, 7 kwietnia 1949 r. bp winnicki Inokientij sam informował pełnomocnika o tym, iż w obwodzie jest bardzo wielu kapłanów nie zarejestrowanych, którzy prowadzą działalność duszpasterską ${ }^{44}$.

W praktyce pozostał również dla władz problem funkcjonowania Autokefalicznej Ukraińskiej Cerkwi Prawosławnej. Władze republikańskie w Kijowie 9 marca 1947 r. pomimo zapewnień pełnomocnika o wyeliminowaniu podobnych problemów, poleciły zarówno pełnomocnikowi, jak i biskupowi, jak najszybszą jej likwidację $e^{45}$. Zobowiązały też pełnomocnika do „nadzorowania sposobu scalania Cerkwi unickiej z Cerkwią prawosławną" dążąc w ten sposób do usuwania problemów związanych z likwidacją unii ${ }^{46}$. W tym celu, poleciły jednocześnie po uzgodnieniu z biskupem winnickim Jakowem wydelegować 3 duchownych - misjonarzy do pracy w zachodnich obwodach Ukrainy ${ }^{47}$.

Pomimo zmasowanego oddziaływania antyreligijnego na terenie obwodu ${ }^{48}$, lokalne władze partyjno-państwowe nie mogły poszczycić się osiągnięciami w procesie ateizacji na swoim terenie. Dla przykładu, we wsi Szeroka Grobla (rejon Chmielnik), na 410 rodzin, tylko 50 było ,ateistycznych”, podobnie we wsi

\footnotetext{
${ }^{39}$ ДАВО, Р-2700, 7c, 529, s. 94.

${ }^{40}$ ДАВО, Р-2700, 7c, 345, s. 223.

${ }^{41}$ ДАВО, Р-2700, 19, 32, s. 16.

42 ДАВО, Р-2700, 19, 30, s. 45.

${ }_{43}$ ДАВО, Р-2700, 19, 6, s. 59.

${ }_{44}$ ДАВО, Р-2700, 19, 7, s. 21.

${ }^{45}$ ДАВО, Р-2700, 19, 5, s. 92.

${ }^{46}$ Tamże, s. 70.

47 ДАВО, Р-2700, 19, 6, s. 6.

${ }^{48}$ J. S z y m ań s k i, Proces ateizacji w obwodzie winnickim (1941-1964), „Roczniki Teologiczne" 49(2002) z. 4, s. 175-204.
} 
Sandraki, na 300 rodzin - 30. Przy czym zauważono, że we wszystkich domach bez wyjątku wisiały ikony. W Sandrakach na 20 urodzonych dzieci - 19 zostało ochrzczonych, na 9 zawartych małżeństw -7 zawarto w cerkwi. W Koziatynie natomiast z 402 związków małżeńskich -290 zawarto w cerkwi ${ }^{49}$. Taka atmosfera sprzyjała stanowisku lokalnych władz partyjno-państwowych, urzędów i instytucji, które wbrew etyce socjalistycznej, dyskredytując oficjalne stanowisko władz centralnych zwracały się z prośbą o pomoc do biskupa i duchowieństwa w sprawie remontów, wydzielenia środków materialnych na bieżące potrzeby lokalnej społeczności ${ }^{50}$. Co więcej, pracownicy instytucji partyjno-państwowych otrzymywali do swej dyspozycji bezpośrednio z kancelarii biskupa środki zbierane na brygadę pancerną, domy dziecka ${ }^{51}$. Nie przeszkadzało to jednocześnie władzom w realizacji „,własnej” polityki religijnej w stosunku do osób wierzących i budynków modlitewnych ${ }^{52}$. Skutkiem tych działań było sukcesywne zmniejszanie się liczby cerkwi. Tylko od 1 października 1944 r. do 1 kwietnia 1945 r. zamknięto 12 cerkwi $^{53}$, a w całym 1945 r. zamknięto ich $17^{54}$.

W pierwszym kwartale $1950 \mathrm{r}$. na terenie obwodu funkcjonowało 700 cerkwi i budynków modlitewnych, w których pracowało 412 kapłanów ${ }^{55}$, rok później już tylko 628 przy liczbie 407 duchownych ${ }^{56}$. W latach 1945-1953 władze doprowadziły do zamknięcia 217 cerkwi i jednego klasztoru żeńskiego ${ }^{57}$. W świetle raportu zastępcy IV wydziału UKGB kapitana Nielidowa - przesłanego do Komitetu Obwodowego (dalej: KO) partii - w obwodzie winnickim działały 643 cerkwie, 392 kapłanów, 2 klasztory, w których przebywało 140 zakonnic i 2 kapłanów ${ }^{58}$. Pełnomocnikowi udało się też wówczas ustalić, że na terenie obwodu są osoby bez święceń kapłańskich wypełniające obowiązki duszpasterskie ${ }^{59}$.

Realizując - jak wspomniano wyżej - „własną” politykę antyreligijną wobec organizacji religijnych władze lokalne, działały wbrew stanowisku władz centralnych, o czym świadczy m.in. pismo pełnomocnika Rady ds. Cerkwi prawosławnej, który wyjaśniał przełożonym sprawę cerkwi zamykanych i wykorzystywanych jako spichlerze: „w wielu rejonach sztucznie wstrzymuje się zwrot cerkwi, jako że nie ma potrzeby w ogóle wykorzystania tych budynków. Z tego wynika, że władze tych rejonów zdecydowały się walczyć z religią" ${ }^{60}$. Często przedstawiciele miejscowych władz wprost żądali od wiernych przekazania cerkwi na lokal-

\footnotetext{
49 ДАВО, Р-2700, 19, 3, s. 11.

50 ДАВО, Р-2700, 19, 4, s. 42.

${ }_{51}$ ДАВО, Р-2700, 19, 3, s. 52.

52 ДАВО, Р-2700, 7c, 10, s. 4-6.

53 ДАВО, Р-2700, 19, 3, s. 29.

54 ДАВО, Р-2700, 19, 4, s. 31.

55 ДАВО, П-136, 30, 180, s. 54. Typowych cerkwi funkcjonowało wówczas 601, a budynków modlitewnych było 99.

56 ДАВО, П-136, 32, 198, s. 61.

57 ДАВО, Р-2700, 19, 23, s. 75.

58 ДАВО, П-136, 40, 272, s. 95-97.

59 ДАВО, Р-2700, 19, 9, s. 77.

${ }^{60}$ ДАВО, Р-2700, 7c, 311, s. 40.
} 
ne potrzeby danej społeczności, np. z tego powodu, że cerkiew znajduje się na gruntach kołchozowych ${ }^{61}$. We wsi Jaryszewka w rejonie winnickim przedstawiciel lokalnych władz usiłował doprowadzić do zamknięcia cerkwi, nakładając na wiernych dodatkowe obciążenia finansowe, o czym informował przewodniczącego RO G. Diemiantiewa pełnomocnik Rady ds. Cerkwi prawosławnej I. Trufanow: „Przy rozpatrywaniu skargi w urzędzie skarbowym ustalono, że wspólnocie parafialnej cerkwi Jaryszewka w 1953 r. i 1954 r. żadnych zobowiązań finansowych nie naliczano, jednak niezależnie od tego przewodniczący Rady Wiejskiej B. Zawalniuk pieniądze od wspólnoty pobrał we wskazanej sumie (1188 rubli, 62 kopiejki), ale ich nie zaksięgował"62. Wspólnoty parafialne nie rezygnowały ze swoich praw, broniły ich „,w niektórych miejscowościach [...], w miejsce zamkniętych budynków kultu, bez zgody pełnomocnika budowano nowe świątynie"63.

Celem ograniczenia aktywności religijnej duchowieństwa i wiernych władze zwierzchnie Rds.KR wciąż instruowały swoich przedstawicieli w obwodach o sposobach przeciwdziałania wobec wspólnot religijnych. Odpowiednie dyrektywy wskazywałyna,,szkodliwość"oddziaływaniaduszpasterskiegonadzieciimłodzież, duchowni bowiem ,,proponowali dzieciom przyprowadzanie ze sobą do świątyni swoich rówieśników, wymagali, by osoby starsze przyprowadzały z sobą do cerkwi swoich wnuków" ${ }^{34}$. Podobne wytyczne zobowiązywały pełnomocników Rds.KR do ujawnienia miejsc kultu, ograniczenia pielgrzymowania, a tym samym i zamykania tzw. świętych miejsc. Chociaż, informacja przekazana przez miejscowego bpa Symona, zaprzeczała w ogóle ich istnieniu. Niepełne dane, jakie pełnomocnik uzyskał $\mathrm{w}$ rozmowach $\mathrm{z}$ duchowieństwem i przedstawicielami wiernych, wskazywały na istnienie tzw. „,cudownych źródeł, ocalałych starych ikon, niezagospodarowanych miejsc, na których wcześniej stały cerkwie i do których pielgrzymowali wierni" ${ }^{\prime 6}$. Stad też władze obwodowe jeszcze w marcu $1959 \mathrm{r}$. zobowiązały władze rejonowe do: - ujawnienia i spisania wszystkich miejsc kultu w rejonie, - jednoczesnego - wraz ze spisem - przedstawienia propozycji „,właściwego" ich zagospodarowania oraz ujawnienia osób i pociągnięcia ich do odpowiedzialności karnej, tzn. definitywnego rozwiązania problemu do 30 kwietnia $1959 \mathrm{r}^{66}$

Kolejny rok realizowanej przez władze polityki wyznaniowej przynosił efekty. Jakkolwiek w latach 1954-1959 zamknięto ,tylko" 34 cerkwie i budynki modlitewne należące do Cerkwi prawosławnej ${ }^{67}$. Naczelnik wydziału KGB w raporcie złożonym organom partyjnym 30 maja 1959 r. stwierdził, że „na terenie obwodu winnickiego funkcjonują 594 cerkwie, w których pracuje ponad 400 kapła-

${ }^{61}$ ДАВО, Р-2700, 7c, 404, s. 78.

${ }^{62}$ Tamże, s. 73.

${ }^{63}$ ДАВО, Р-2700, 7c, 311, s. 104. Budynki modlitewne wybudowane wówczas były we wsiach:

Krikowcy, Kurianicy, Słobodka.

${ }^{64}$ ДАВО, П-136, 45, 291, s. 11.

${ }^{65}$ ДАВО, П-136, 48, 214, s. 45-48.

${ }^{66}$ ДАВО, Р-2700, 7c, 478, s. 61ab.

${ }^{67}$ ДАВО, Р-2700, 19, 23, s. 75. 
nów. W tej liczbie 60 pochodzi z zachodnich obwodów" 68 . W podobnym raporcie z końca 1960 r. informowano o 591 cerkwiach i 2 klasztorach żeńskich, w których posługę kapłańską sprawował arcybiskup i 378 kapłanów ${ }^{69}$. W tym czasie w 20 cerkwiach nie sprawowano już liturgii od 18 miesięcy, a w 100 innych świątyniach tylko od czasu do czasu, 350 cerkwi było zaś oddalonych od siebie od 500 metrów do $3 \mathrm{~km}$. Za powyższą sytuację obwiniano I. Trufanowa pełnomocnika Rady ds. Cerkwi prawosławnej w obwodzie winnickim, który - jak stwierdzono - „nie podejmował działań zmierzających do ograniczenia działalności arcybiskupa, który w celu ożywienia religijności w zanikających wspólnotach kierował tam kapłanów z innych rejonów”. W tym czasie w wielu miejscowościach bez zezwolenia budowano budynki dla potrzeb cerkwi i przebudowywano stare, organizowano pielgrzymki i sprawowano liturgię ,pod odkrytym niebem”. Odtąd nastąpiły zmiany w postępowaniu władz. Na podstawie instrukcji Rady ds. Cerkwi prawosławnej zaprzestano wydawania pozwoleń kapłanom na pełnienie posługi duszpasterskiej w parafiach i zalecono ponowne rozpatrzenie funkcjonowania parafii w budynkach wynajmowanych dla kultu albo korzystających z nich nielegalnie $^{70}$. W następstwie działań władz lokalnych i pełnomocnika Rady ds. Cerkwi prawosławnej w $1960 \mathrm{r}^{71}$ zamknięto 60 cerkwi, przeznaczając je na kluby, sale gimnastyczne i magazyny ${ }^{72}$.

Cały czas też prasa obwodowa zarzucała swoich czytelników informacjami o odchodzeniu z szeregów duchowieństwa kapłanów prawosławnych ${ }^{73}$ i wzrastającej świadomości ludu pracującego, który spontanicznie zamykał cerkwie, ,przeżytki minionego okresu" "74.

68 ДАВО, П-136, 48, 214, s. 100-102. Raport naczelnika KGB obwodu winnickiego zawiera ocenę działalności pełnomocnika Rady ds. Cerkwi prawosławnej, który przedstawiony jest w nim jako obrońca stanu posiadania Cerkwi prawosławnej i jej duszpasterzy. „Sekretarz biskupa - G. Pałaj wśród swoich znajomych opowiadał, że jeśli by tow. Trufanow działał zdecydowanie w tych sprawach, to biskup Symon zawsze podtrzymałby jego propozycje. Ze słów Pałaja, Symon gotów był zamknąć 30\% mało dochodowych parafii z tym, żeby jeden kapłan obsługiwał 2-3 parafie. [...] Nie było wypadku, by on odmówił zarejestrowania jakiegokolwiek duszpasterza. [...] do $1953 \mathrm{r}$. zamykano każdego roku kilkadziesiąt cerkwi, to od kiedy on kierował urzędem 2-3 cerkwie i to nie zawsze".

${ }^{69}$ ДАВО, П-136, 48, 214, s. 152. W tej liczbie 69 kapłanów było wcześniej skazanych za antysowiecką działalność.

${ }^{70}$ Tamże, s. 168-169.

${ }^{71}$ ДАВО, Р-2700, 6, 1880, s. 39. Według tej informacji w 1962 r. zamknięto 42 cerkwie.

72 ДАВО, П-136, 48, 214, s. 9.

${ }^{73}$ П. Д а р м а н с ь к и й, Чому я порвав з релігією. Розповідь колишнього священика, кандидата богослов'я, „Вінницька Правда” 4 III 1958, s. 3; М. С п а с ь к и й, Чому я зрікся церкви, „Вінницька Правда” 12 VII 1959, s. 3; А. Пи в о в а рч у к, Чому я пориваю з иерквою, „Вінницька Правда” 1 VIII 1959, s. 3; О. О с и п о в, Відказ ві д рел ігі ї - Сдино вірний шлях, „Вінницька Правда” 9 XI 1959, s. 3-4; І. Ш а м р а й, Моя остання сповідь, „Вінницька Правда” 8 I 1960, s. 3; П. 3 а л і т и н к е в и ч, Чому я став атеїстом..., „Вінницька Правда” 3 VII 1962, s. 4; I . 3 и с ь к о, Не хочу служити неправому ділу, „Вінницька Правда” 7 VIII 1962, s. 4.

${ }^{74}$ М. Ч о р н и й, Люд робочий цееркви не хоче, „Вінницька Правда” 29 IX 1959, s. 3. 
Zaostrzenie polityki antyreligijnej nastąpiło w 1959 r. Wówczas też władze podjęły zdecydowanie wrogie działania wobec Cerkwi prawosławnej. Organizacjom partyjnym $\mathrm{w}$ poszczególnych rejonach obwodu przesłano odpowiednie instrukcje o charakterze agitacyjno-ideologicznym ${ }^{75}$. Zgodnie z tymi wskazaniami m.in. - pełnomocnik rady I. Trufanow - przesłał kierownikowi Wydziału Propagandy i Agitacji KO KP Ukrainy w Winnicy tow. I. P. Gruszczenko i sekretarzowi RO G. Kosakowskiemu spis 110 cerkwi i budynków modlitewnych ${ }^{76} \mathrm{~W}$ odniesieniu do których na miejscach wymagane było podjęcie odpowiednich działań zmierzających do ich ekonomicznego osłabienia i w konsekwencji likwidacji ${ }^{77}$. Z pewną satysfakcją przedstawiciel Rady ds. Cerkwi prawosławnej w Kijowie G. Pinczuk informował KC KP/b/ Ukrainy: „bardziej zdecydowana presja na duchowieństwo i przemyślane podejście do tej sprawy [zamykania cerkwi] pełnomocników Rady przyniosły znaczne możliwości i w 1960 r. pozbawiono prawa, tzn. ograniczono działalność znacznej liczby organizacji religijnych - parafii”. Tym działaniom sprzyjało postanowienie KC KPZR z 13 stycznia 1960 r. ${ }^{78}$ Pełnomocnik Rady ds. Cerkwi prawosławnej przyznał, że we wsi Swoboda Jałtuszkowska (rejon barski), w 1961 r. władze lokalne niezgodnie z obowiązującym prawem zamknęły cerkiew ${ }^{79}$. W wyniku zdecydowanych posunięć władz na początku

75 ДАВО, Р-2700, 19, 23, s. 75.

${ }^{76}$ Tamże, s. 69-71. Według poniższego spisu likwidacji podlegały cerkwie i budynki modlitewne w rejonach: barskim: Łuka Barskaja, Pietrowka, Jałtuszków, Swoboda Jałtuszkowska; bracławskim: Zabużie; winnickim: Kozińcy i Kochanowka; hajseńskim: Kiśliaki, Kunka, Mieleszki, Nosowcy; żmeryńskim: 2 cerkwie w Żmerynce, Kudijewcy, Łopatyńcy; ilinieckim: Ługowoje, Morozowka, Słobodiszcze, Czortorija, Jakubowka; koziatyńskim: Siestrienowka; kalinowskim: Żigałowka, Szepijewka; komsomolskim: Brodieckoje, Żeżelew; kryżopolskim: Andrijaszewka, Goriaczkowka, Goriaczkow Swoboda, Krikliwiec Wołos., Krikliwiec Russo., Radiańskoje, Ternowka Wielka, Ternowka Mała, Cibulewka Nowa, Cibulewka Stara; lipowieckim: Kosakowka, Popowka, Priłuka Nowa, Priłuka Stara; lityńskim: Winnikowcy, Gorbowcy, Iwcza, Łysogorka, Majdan Suprunowskij, Triebuchi; mohylew-podolskim: Wojewodczińcy, Iwanowka, Łiadowa, Sadowa, Subbotowka, Szłyszkowcy; murowano-kuryłowieckim: Boguszewka, Popieluchi; niemirowskim: Potoki; Hwostowcy, Jary; oratowskim: Żiwotowka, Żiwotowka Nowa; piesczańskim: Studiennoje; pliskowskim: Adamowka, Skomoroszki, Czełnowcy, pogrebyszskim: Bułai, Byrkowcy, Ordyńcy, Sarażińcy, Stepanki; teplickim: Sokirjany; tomaszpolskim: Rusawa Wielka, Rusawa Gołowo, trostianieckim: Łukaszewka; tulczyńskim: Biełousowka II, Wasilewka, Guta, Mańkowka; tywrowskim: Kleszczew, Michaiłowka, Czeremoszne; ułanowskim: Pagurcy, Sułkowka, Taraski, Torczin; chmielnickim: Żdanowka, Łuka, Saierbinowka, Ugrinowka, 2 cerkwie w Cmielniku; czerniowieckim: Babczyńcy I, Babczyńcy II, Bezwodnoje, Wiły Jarugskie; czeczelnickim: Ługi Swoboda, Ługi Stare, Michajłówka, Olgopol, Jakubowka; szarogrodzkim: Żdanowo [Murafa], Kalitinka, Łozowaja I, Łozowaja II, Murafa Nowa, Pokutino, Sadkowcy; szpikowskim: Żabokricz, Torkow; jampolskim: Kaczkowka, Kosnica Wielka, Kosnica, Ratusz. Na końcu spisu, poczyniono uwagę, że „Spis ma charakter orientacyjny, i na miejscu istnieje możliwość dokonania korekty".

77 Tamże, s. 68.

${ }^{78} \mathrm{~B}$. В о й н а ло в и ч, Політико-правові засади національно-релігійної політики в $У_{\kappa-}$ раїні кіния 50-X - першої половини 60-Х років, w: Історія України. Маловідомі імена, події, факти, П.Т. Тронько, О. Г. Бажан, Л.А. Гречина, Київ 1997, s. 198-200.

${ }^{79}$ ДАВО, Р-2700, 19, 71, s. 68. 
1961 r. otwartych było już tylko 531 cerkwi $^{80} \mathrm{i}$ budynków modlitewnych ${ }^{81}$. W tym też roku pod wpływem synodu wprowadzono pewne zmiany w statucie diecezjalnym. Odtąd kapłan był zależny od władzy diecezjalnej, wybieranej przez lokalną administrację. Tym samym zobowiązywał się do uzgadniania planu pracy duszpasterskiej z przedstawicielem władzy oraz dostarczania spisu osób korzystających Z sakramentów św. ${ }^{82}$

Ograniczeniu działalności Cerkwi prawosławnej sprzyjało też przyjęcie przez winnicką RO postanowienia ${ }^{83}$ Rady Ministrów (dalej: RM) Ukrainy z 1 listopada $1958 \mathrm{r}$. w sprawie zmniejszenia liczby klasztorów na terenie obwodu ${ }^{84}$. Z podobnymi inicjatywami wystąpiły też władze innych obwodów. RM Ukrainy zdecydowała wówczas o zamknięciu 9 klasztorów. Ministrowie przyjmując propozycję pełnomocnika Rady ds. Cerkwi prawosławnej, RO i Rady Rejonowej (dalej: RR) w Barze, zadecydowali o zamknięciu klasztoru w tym mieście. Zakonnicom w zależności od ich wieku zaproponowano zatrudnienie w zakładach pracy, umieszczenie w domach starców lub - w miarę możliwości - zorganizowanie dla nich miejsc w innym klasztorze. Dobra, jakie po nich pozostały, przekazano do dyspozycji władz lokalnych. Budynki klasztorne przeznaczono na przedszkola, szkoły, internaty, domy starców oraz na potrzeby służby zdrowia i instytucji kulturalnych ${ }^{85}$. W przypadku klasztoru w Barze - zgodnie z decyzją RO - miał się w nim mieścić dom pioniera i szkoła muzyczna ${ }^{86}$. W tym celu pełnomocnik Rady ds. Cerkwi prawosławnej Trufanow 12 grudnia 1959 r. przesłał sekretarzowi KO KP Ukrainy A. Olejnikowi stosowne instrukcje zmierzające do zamknięcia klasztoru i przesiedlenia w miesiącu maju 1960 r. sióstr zakonnych do klasztoru w Brahiłowie $^{87}$.

Według danych RO z 1 stycznia 1962 r. na terenie obwodu było 400 cerkwi

${ }^{80}$ ДАВО, Р-2700, 19, 25, s. 157. W poszczególnych obwodach Ukrainy działalność duszpasterska prowadzona była m.in. w: 234 cerkwiach obwodu odeskiego; 279 - kijowskiego; 298 - czernichowskiego; 327 - chmielnickiego; 1207 - lwowskiego; 777 - tarnopolskiego; 639 - iwanofrankowskiego.

${ }^{81}$ ДАВО, Р-2700, 7c, 514, s. 45.

${ }^{82}$ В о й н а л о в и ч, Що насправді койлось, s. 155; Ж у к о в с ь к и й, Сучасний стан, s. 47.

${ }^{83}$ В о й н ал о в и ч, Що насправді коїлось, s. 152-153. Wcześniej, 16 IX 1958 r. podobne postanowienie przyjęła RM ZSRR. Patriarcha Aleksiej zaaprobował wówczas zamknięcie 29 z 63 istniejących na terenie ZSRR klasztorów.

${ }_{84}^{84}$ ДАВО, Р-2700, 6, 1417, s. 26.

${ }^{85}$ ДАВО, Р-2700, 7c, 488, s. 94-97; ДАВО, П-136, 50, 221, s. 66-67; В о й н а л о в и ч, Що насправді койлось, s. 152-153; t e n ż e, Чорні дні , чорного” духовенства. Ліквідачія православних монастирів в Україні в ході антирелігійної компанії другої половини 50-х - першої половини 60-х рp., „3 архівів ВУЧК ГПУ НКВД КГБ” 1/2(1995), s. 211-212. Sprawa zamknięcia klasztorów była konsultowana również z hierarchią Cerkwi prawosławnej. Patriarcha Aleksiej swoją zgodę wyraził 4 IV 1959 roku. Zdaniem Karpowa, przewodniczącego Rady ds. Cerkwi prawosławnej powodem zamknięcia klasztorów było m.in. to, że „wiele klasztorów [...] jest ogniskiem chorób wenerycznych i innych. Zakonnicy nie chcą korzystać z pomocy lekarskiej, rozpowszechniają 'zabobony'.

${ }^{86}$ ДАВО, Р-2700, 6, 1417, s. 26.

${ }^{87}$ ДАВО, Р-2700, 19, 23, s. 90-96. 
i 46 budynków modlitewnych, w tym: w mieście 13 cerkwi, 422 na wsi i 11 w dzielnicach robotniczych. Pracowało w nich 259 kapłanów, 3 diakonów i arcybiskup. W liturgii brało udział: 6180 wiernych w miastach i 59670 na wsiach ${ }^{88}$. Od 1945 r. do 1962 r. władze zamknęły 5 cerkwi w rejonie czerniowieckim ${ }^{89}$, 7 w rejonie hajsyńskim $^{90}, 7 \mathrm{w}$ lipowieckim ${ }^{91}, 4 \mathrm{w}$ ułanowskim ${ }^{92}$. Samorządy rejonowe Litynia $^{93}$ i Bracławia ${ }^{94}$ również zamknęły wiele cerkwi na swoim terenie. W tym czasie np. decyzję o zamykaniu niektórych cerkwi w rejonie ilinieckim podejmowała niejednokrotnie społeczność danej miejscowości podczas ogólnych zebrań ${ }^{95}$. Działania takie najczęściej inicjowane były przez pełnomocnika i lokalne władze. Za jedno z takich działań pełnomocnik został skarcony przez swoich przełożonych w Kijowie. Potrzeba przejęcia cerkwi dla potrzeb społecznych wsi Nepedowka została tak przedstawiona lokalnej społeczności, że podczas głosowania, kto za cerkwią, a kto za klubem ujawniła, że za cerkwią było 542 mieszkańców wsi, a za klubem ,jeden tylko przedstawiciel kołchozu"96.

Dnia 20 kwietnia 1961 r. RO w Winnicy podjęła decyzję o zamknięciu cerkwi w rejonach: tomaszpolskim, niemirowskim, lityńskim, chmielnickim, hajsyńskim i berszadzkim ${ }^{97}$. Podobną decyzję podjęto 20 czerwca wobec 8 cerkwi $^{98}, 5$ sierpnia wobec $18^{99}$, 20 września - 14 cerkwi ${ }^{100}$, a 3 listopada -4 cerkwi $^{101}$. Wtedy też zo-

${ }^{88}$ ДАВО, Р-2700, 6, 1901, s. 74-75.

89 ДАВО, П-136, 51, 142, s. 26.

90 ДАВО, Р-2700, 6, 1901, s. 93.

${ }^{91}$ Tamże, s. 138-139. Według przewodniczącego RR w Lipowcu ,jeszcze zostało otwartych 10 cerkwi. Na 4 z nich w ciągu miesiąca zostaną przygotowane materiały umożliwiające ich zamknięcie. Potem przygotujemy materiały umożliwiające zamknięcie reszty”.

${ }^{92}$ Tamże, s. 143.

${ }^{93}$ Tamże, s. 107-108.

${ }^{94}$ Tamże, s. 120-121. W 1962 r. w rejonie bracławskim było 14 cerkwi, otwartych - 7, wyrejestrowanych -2 , a wobec 5 prowadzono działania zmierzające do ich zamknięcia.

${ }^{95}$ І. Бо н д а р е н ко, Д. Ко б е ц ь, І. Д о в го п о л и й, І. Мар'я н ч у к, Чому ми закрили церкву, „Вінницька Правда” 24 III 1962, s. 4.

${ }^{96}$ ДАВО, Р-2700, 19, 7, s. 32.

${ }_{97}$ ДАВО, Р-2700, 6, 1654, s. 149-152.

${ }_{98}$ ДАВО, Р-2700, 6, 1657, s. 136-138.

99 ДАВО, Р-2700, 6, 1660, s. 64-67; П а н ч е н к о, Релігія в українському суспільстві, s. 202203.

100 ДАВО, Р-2700, 6, 1662, s. 173-175. Decyzja nr 683 z 20 września 1961 r. brzmiała: „O wyłączeniu z użytkowania organizacji religijnych pomieszczeń-cerkwi, które przed wojną wykorzystywane były jako kluby wiejskie. Rozpatrując prośby przedstawicieli Rad Rejonowych: Baru, Żmerynki, Komsomolska, Kryżopola, Lipowca, Iliniec, Teplika, Czeczelnika i Jampola; wnioski pełnomocnika Rady ds. Cerkwi prawosławnej w obwodzie winnickim o wyłączenie pomieszczeńcerkwi z użytkowania wspólnot parafialnych, i biorąc pod uwagę, że przed wojną (1941-1945) w pomieszczeniach byłych cerkwi, znajdujących się we wsiach [...] mieściły się kluby wiejskie, we wsiach [...] mieściły się spichlerze, RO zdecydowała:

1. Wyłączyć pomieszczenia-cerkwi z użytkowania wspólnoty parafialnej [...], zaaprobować decyzję RR w Barze zezwalającą użytkować pomieszczenie-cerkwi, jako klubu wiejskiego".

101 ДАВО, Р-2700, 6, 1663, s. 78-79. Decyzja nr 714 z 3 listopada 1961 r. 
bowiązano rady miejskie i rejonowe do wykorzystywania zamkniętych cerkwi ${ }^{102}$ i do odsunięcia duchowieństwa parafialnego od zarządzania sprawami cerkwi ${ }^{103}$.

W związku z przyjęciem 16 marca 1961 r. przez RM ZSRR rozporządzenia o zaostrzeniu kontroli przy przestrzeganiu ustawodawstwa o kultach, a 29 kwietnia przez RM Ukrainy, RO wydała podobne zalecenie RR w obwodzie, zobowiązując je do nadzorowania podległych sobie instytucji. Jednocześnie uprzedzono biskupa Symona i dziekanów o ewentualnych konsekwencjach w przypadku naruszenia przez nich prawa o kultach ${ }^{104}$.

Powyższe „osiągnięcia” władz w zwalczaniu wspólnot religijnych, zamykaniu cerkwi możliwe były również dzięki poparciu hierarchów prawosławnych. Do nich niewątpliwie należał miejscowy biskup diecezji winnickiej, który swoją decyzję o zamknięciu soboru katedralnego, dawnego kościoła dominikańskiego thumaczył brakiem ducha modlitwy w tej świątyni. W liście do metropolity kijowskiego i galickiego, patriarszego egzarchy Ukrainy Joana, napisał on: „Winnicki katedralny sobór - to budynek byłego kościoła i klasztoru dominikańskiego. Usytuowany w centrum miasta, w sąsiedztwie budynków użyteczności publicznej, instytucji państwowych i oświatowych. Główne wejście soboru wychodzi na centralną ulicę miasta. [...] Niedawno wspólnota religijna Katedralnego Soboru Przemienienia i sąsiedniej cerkwi Narodzenia Bogurodzicy zjednoczyły się, utworzyły jedną „dwadcatkę" i organy wykonawcze, a także podjęły decyzję o przejściu do budynku cerkwi Narodzenia Bogurodzicy. Dlatego i ja [biskup] zdecydowałem się przenieść sprawowanie liturgii do świątyni Narodzenia Bogurodzicy, znajdującej się 1,5 km od soboru. [...] Po ustnym wyjaśnieniu wyżej wspomnianych spraw i otrzymaniu Waszego Błogosławieństwa z życzeniami pomocy Bożej, zorganizowano przewiezienie ikonostasu, a także wszelkiego dobytku z katedralnego soboru, znajdującego się w byłym rzymskokatolickim kościele do naszej prawosławnej cerkwi Narodzenia Bogurodzicy"105.

Realizując konsekwentnie swoją politykę w stosunku do Cerkwi, w niedługim czasie - jak informował przewodniczącego RO M. Słobodianiuka pełnomocnik Rady ds. Cerkwi prawosławnej w obwodzie S. Kulikow -7 duchownych pozbawiono prawa do spełniania posługi duszpasterskiej, 10 kapłanów, w tym 4 dziekanów, przeniesiono na gorsze - w znaczeniu materialnym - parafie, a 11 ostrzeżono o naruszeniu prawa ${ }^{106}$. Według innego sprawozdania Kulikowa z 16 listopada nastąpiły dalsze zmiany. I tak: 16 duchownych pozbawiono prawa do spełniania posługi duszpasterskiej, 18 kapłanów, w tym 6 dziekanów, przeniesiono na gorsze finansowo parafie, 14 zaś udzielono napomnienia ${ }^{107}$.

W styczniu 1962 r. KO zobowiązał Rady Rejonowe do dostarczenia informacji na temat przeznaczenia i wykorzystania budynków kultu, w których nie ze-

\footnotetext{
102 ДАВО, Р-2700, 6, 1880, s. 41.

${ }_{103}$ ДАВО, Р-2700, 6, 1659, s. 213.

104 ДАВО, Р-2700, 7c, 514, s. 43-44.

${ }_{105}$ ДАВО, Р-2700, 19, 27, s. 133.

106 ДАВО, Р-2700, 7c, 514, s. 43-44.

${ }^{107}$ Tamże, s. 56.
} 
zwolono na prowadzenie działalności duszpasterskiej w latach 1960 i $1961^{108}$. W kolejnym piśmie - z czerwca 1962 r. - stwierdzono, że w 1960 r. nie pozwolono na prowadzenie działalności w 42 parafiach, a w 1961 r. -83 . Decyzji tych nie respektowały jednak lokalne władze, ponieważ na 125 wyrejestrowanych cerkwi zamknęły tylko 29. Budynki wykorzystywano jako kluby, biblioteki, sale gimnastyczne i do celów gospodarczych na magazyny i spichlerze ${ }^{109}$. Pełnomocnik Rady ds. Cerkwi prawosławnej S. Kulikow powiadomił swojego przełożonego G. Pinczuka, że na terenie obwodu ujawniono funkcjonowanie 448 parafii prawosławnych, które korzystały z 446 cerkwi i budynków modlitewnych. Dwie parafie nie miały budynków kultu (Stanisławczyk i Winnikowce), 26 obiektów sakralnych było zbudowanych lub zakupionych po II wojnie światowej, 12 wynajmowanych u osób prywatnych, a 8 u władz lokalnych ${ }^{110}$.

Realizując politykę unicestwienia organizacji religijnych, przedstawiciele Rady ds. Cerkwi prawosławnej - zgodnie ze wskazówkami przełożonych - usiłowali również nie dopuścić młodych ludzi do podejmowania nauki w seminariach duchownych. I tak 20 lipca 1962 r. pełnomocnik Rady ds. Cerkwi prawosławnej w Leningradzie i obwodzie leningradzkim G. Żerinow meldował pełnomocnikowi obwodu winnickiego, że kandydatem do seminarium w Leningradzie jest J. Babik, mieszkaniec wsi Lipowki (rejon Tomaszpol), prosząc jednocześnie „o przekazanie odpowiednich materiałów, które mogłyby przeszkodzić w przyjęciu go do seminarium i podjęcie odpowiednich kroków na miejscu" "11. Podobna informacja z 8 sierpnia tegoż roku - tym razem przekazana przez pełnomocnika Radyds.Cerkwiprawosławnejobwodu winnickiegodourzędóww KijowieiOdessie - dotyczyła N. Dobrowolskiego, mieszkańca wsi Pilipowka (rejon Berszada), który był kandydatem do seminarium w Odessie. Pełnomocnik ,,poinformował KO partii i Prezydium Komsomołu, że w obecnym czasie wobec Dobrowolskiego i jego krewnych prowadzi się odpowiednie działania. Zarządzający diecezją winnicką - biskup Józef odmówił Dobrowolskiemu wystawienia rekomendacji potrzebnej do przyjęcia do seminarium" ${ }^{112}$. Powyższe działania władz nie pozostawały bez echa, wierni odwoływali się do najwyższych instancji partyjno-państwowych $^{113}$.

Tylko w latach 1961-1964 na terenie obwodu wykreślono z ewidencji 224 ${ }^{114}$

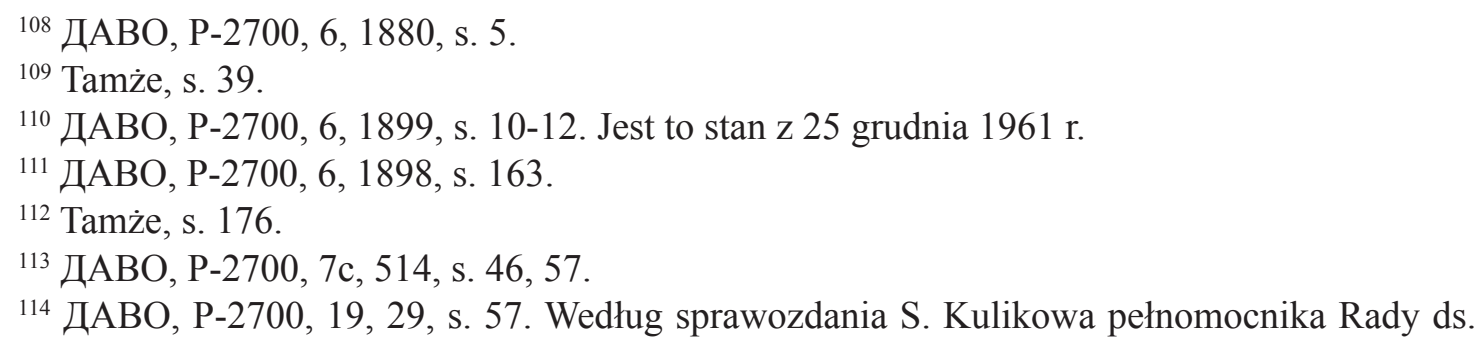
Cerkwi prawosławnej w obwodzie winnickim, w latach 1960-1964 na terytorium tegoż obwodu Rada Obwodowa za zgodą Rady ds. Cerkwi prawosławnej wyłączyła z użytkowania wspólnot religijnych 220 cerkwi i budynków modlitewnych. Wyłączone budynki wykorzystywano: 35 - jako kluby, sale gimnastyczne, pracownie szkolne, magazyny wiejskie; 8 - rozebrano jako awaryjne; 161 - jako spichlerze i magazyny wiejskie; 16 - nie zagospodarowano. W tej liczbie: w rejonie barskim - Bachtyn, Szipinki, Swoboda Jałtuszkowska; w berszadzkim - Britawka, Kureniewka, Liubomir- 
wspólnoty prawosławne. Zezwalając na działalność zgodną z prawem o kultach w 1964 r. 367 parafiom prawosławnym ${ }^{115}$. W 1965 r. na terenie obwodu funkcjonowało 350 cerkwi, w których pracowało jeszcze 183 kapłanów ${ }^{116}$, spośród których tylko 10 ukończyło seminarium po $1945 \mathrm{r} .{ }^{117} \mathrm{Z}$ tych 350 cerkwi, 330 funkcjonowało na wsiach, a 20 w miastach. Spośród tych 350 cerkwi, liturgię celebrowano 2-3 razy w tygodniu, tylko w jednej, w 201 cerkwiach w niedzielę i święta, w pozostałych 149 liturgii nie sprawowano ,rok i dłużej”. Dla przykładu takich cerkwi w rejonie barskim było 16; w berszadzkim - 8; hajseńskim - 12; koziatyńskim - 9; mohylew-podolskim - 14; chmielnickim - $13^{118}$.

Ogólnie w ciągu 20 lat od zakończenia drugiej wojny światowej - jak twierdzi P. Panczenko - na Ukrainie wyrejestrowano z ewidencji państwowej 4847 cerkwi i budynków modlitewnych Rosyjskiej Cerkwi prawosławnej. Szczególnie intensywne działania władz przeciwko osobom wierzącym miały miejsce w latach 1959-1964, w tym czasie wyrejestrowano 81,1\% cerkwi i budynków modlitewnych ${ }^{119}$.

ka; w hajsyńskim - Wiesiełowka, Kunka, Mieleszkow; w ilinieckim - Słobodiszcze; w koziatyńskim - Mołotkowcy, Wiernigorodok; w kalinowskim - Glinka, Zaliwańszczyna; w lipowieckim Kosakowo, Nowa Priłuka. Rady Rejonowe wspomnianych rejonów prosiły o wyrażenie zgody na przebudowę cerkwi rozmieszczonych we wspomnianych wioskach i umieszczenie w nich klubów i sal gimnastycznych.

115 Tamże, s. 26.

116 ДАВО, Р-2700, 6, 2109, s. 1.

117 ДАВО, Р-2700, 19, 29, s. 3.

118 Tamże, s. 17, 26-43, 50-55; ДАВО, P-2700, 6, 2113, s. 103-108; Ks. J. S z y m a ń s k i , Sytuacja religijna na terenie obwodu winnickiego w 1965 r. wedlug raportu petnomocników Rad: ds. Kultów Religijnych i Cerkwi prawosławnej, „Roczniki Teologiczne” 51(2004) z. 4, s. 229-237.

119 П а н ч е н ко, Релігія в українському суспільстві, s. 204-205. 


\section{DER ZUSTAND UND DIE SITUATION DER ORTHODOXEN KIRCHE IM GEBIET DES BEZIRKS WINNICA IN DEN JAHREN 1941-1965}

\section{Zusammenfassung}

Der Bezirk Winnica in Podolien (Ukraine) wurde am 27. Februar 1932 geschaffen und umfaßt eine Fläche von $26500 \mathrm{~km}^{2}$. Auf seinem Territorium gab es im Jahre 19371899 Dörfer, 16 Arbeitersiedlungen und 7 Städte, die 1941 von 2390000 Personen und 1946 von 2037000 Personen bewohnt wurden. Bis zur Oktoberrevlution waren in diesem Bezirk 1100 orthodoxe Kirchen geöffnet. Aber ab 1932 begann der Prozeß der massenhaften Schließung von Gebetshäusern und Kirchen. Er wurde mit solcher Konsequenz realisiert, daß bereits im Jahre 1937 offiziell keine religiöse Gemeinschaft mehr existierte.

Die praktische Möglichkeit einer Wiedergeburt des religiösen Lebens im Osten entstand erst nach dem Angriff Deutschlands gegen die UdSSR am 22. Juni 1041. In der Zeit der deutsch-rumänischen Besatzung von 1941 bis 1943 waren in diesem Gebiet 848 orthodoxe Kirchen und Gebtshäuser geöffnet.

Nach dem Einmarsch sowjetischer Truppen in dieses Gebiet Mitte des Jahres 1944 konnten die Behörden die in den zwanziger und dreißiger Jahren realisierten Methoden des kämpferischen Atheismus nicht mehr anwenden und die während der Okkupationszeit konsolidierte Menge der Gläubigen nicht mehr mißachten. Die Tätigkeit der orthodoxen Kirche wurde vom Rat für Orthodoxe Kirchenangelegenheiten kontrolliert. Die Diözese Winnica, die das Territorium des Bezirks Winnica umfaßte, bildete eine der 19 zum Kiewer Exarchat gehörenden Diözesen. 1944 gab es auf ihrem Gebiet 839 orthodoxe Kirchengemeinden, vier Frauenklöster und ein Männerkloster. In der Seelsorge waren 194 Priester und 4 Diakone tätig. Am 1. Januar 1945 genehmigten die Behörden 997 religiösen Gemeinschaften, davon 839 orthodoxen, formell die Durchführung der Seelsorgetätigkeit. Dennoch kam es in den Jahren 1945-1953 zur Schließung von 217 Kirchen und eines Frauenklosters.

Entschieden feindliche Aktivitäten gegen die orthodoxe Kirche unternahmen die sowjetischen Behörden erst 1959. Im Jahre 1965 funktionierten auf dem Gebiet dieses Bezirks 350 Kirchen, in denen noch 183 Priester arbeiteten. Insgesamt wurden innerhalb der 20 Jahre nach Beendigung des 2. Weltkrieges in der Ukraine 4847 Kirchen und Gebertshäuser der Russisch-Orthodoxen Kirche aus dem staatlichen Evidenzregister gestrichen. Zu besonders intensiven Übergriffen staatlicher Stellen gegen die Gläubigen kam es in den Jahren 1959-1964; in dieser Zeit wurde 81,1\% der Kirchen und Gebetshäuser die Genehmigung entzogen. 